\title{
Preliminary investigation on the diversity of plankton and periphyton from a freshwater pond stocked with rohu, Labeo rohita (Hamilton, 1822)
}

\author{
Surjya Kumar Saikia ${ }^{1 *}$ - Samar Kumar Saha² • Sandip Majumder ${ }^{1}$ \\ ${ }^{1}$ Fish Biology and Aquatic Ecology Laboratory, Department of Zoology, Visva Bharati University, Santiniketan, West Bengal, India, Pin-731235 \\ ${ }^{2}$ Fish Biology Unit, Department of Zoology, Visva Bharati University, Santiniketan, West Bengal, India, Pin-731235 \\ *Corresponding author: surjyasurjya@gmail.com
}

\begin{abstract}
A rapid study was performed to analyse the diversity of plankton and periphyton from a freshwater pond stocked with Labeo rohita (Hamilton), an Indian major carp. The pond was installed with bamboo substrates for periphyton growth. Diversity and richness of planktonic and periphytic communities were observed for six months. Results showed little difference in richness between plankton and periphyton in the pond, but percentage abundance of Bacillariophyceae was more on substrates than in water column. Shannon Wiener diversity and evenness values were also high for both plankton and periphyton. It was concluded that in presence of $L$. rohita, plankton and periphyton maintains indifferent algal richness and high Shannon Wiener diversity.
\end{abstract}

Keywords: Periphyton; Shannon-Wiener diversity; Labeo rohita; Bacillariophyceae

\section{INTRODUCTION}

Plankton play significant role in growth and development of aquatic organisms in upper trophic levels. They always occupy the sole interest of aquatic biologists for their trophic position in aquatic food chain. Phytoplankton, in particular, has a critical role in primary production, nutrient cycling, and food webs in aquatic ecosystems (Dawes, 1998). In sea water, more than $95 \%$ primary production is contributed exclusively through phytoplankton (Lewis, 1974). They are the source of food for numerous other organisms, especially zooplankton and functions as an important link between detritus nutrients and zooplankton with a significant fraction of nutrient transfer to secondary production. These are regarded as best natural food for aquatic herbivorous filter feeders. Like phytoplankton, periphyton, a layer of microorganisms that forms on many submerged surfaces in water, dominated by algae, is a primary food source for grazing invertebrates and some vertebrates (Feminella and Hawkins, 1995). It has similar role in transferring primary productivity to secondary productivity in aquatic ecosystem. Being preferable food for herbivores, both phytoplankton and periphyton are greatly regulated by aquatic organisms feed on them. Hence their abundance and diversities are influenced by the presence of herbivorous grazers. There are recent researches in which several herbivorous fish has been projected as efficient grazer of periphyton for conversion of algal biomass to fish biomass (Saikia and Das, 2009a; Saikia et al., 2013a). Of these fishes, rohu Labeo rohita (Hamilton) has been reported to feed both on plankton and periphyton (Rahman et al., 2008). Knowledge on phytoplankton and periphyton diversity due to its presence will bear great significance for understanding the grazerresource interaction in aquatic ecosystem.

\section{MATERIALS AND METHOD}

\section{Experimental set up}

The study has been performed in a conventional fish pond of $2.5 \mathrm{~m}$ depth and an area of $50134 \mathrm{~m}^{2}$ from July 2012 to December 2012.Bamboo substrates were installed at an interval of $1 \mathrm{~m}$ from each other for periphyton growth. Fry of average length of $20 \mathrm{~mm}$ were released 15 days before first sampling at a rate of 1 fry $/ 0.5 \mathrm{~m}^{3}$.

\section{Sampling}

\section{Plankton}

Plankton from the surface water were collected carefully avoiding any disturbances to water. A mixed sample of $30 \mathrm{~L}$ from different locations of the pond was poured through $76 \mu \mathrm{m}$ plankton net to capture net phytoplankton and zooplankton (APHA 1998) and finally preserved in $4 \%$ formalin in $25 \mathrm{ml}$ glass vial.

\section{Periphyton}

Periphyton were scrapped randomly from bamboo surface with a fine scalpel blade until there was no mark of periphyton layer (visible with naked eyes) on the surface. The area scrapped for periphyton sampling has been measured. To maintain uniformity, a near to square sized area has been scrapped for periphyton sampling. All samples of plankton and periphyton were preserved in $4 \%$ formalin for further observation.

\section{Identification and quantification}

Organisms were identified following standard manuals (Pentecost, 1984; Edmondson, 1992) under an inverted microscope (Dewinter plus) in 400 and 600 magnifications. 
Where necessary, identity of algae was confirmed through web based information (www.algaebase.org). For quantitative study, samples were collected and centrifuged at the rate of $1500 \mathrm{rpm}$ for 10 minutes. The volume is then reduced to $10 \mathrm{ml}$ with $4 \%$ formalin and kept in cool and shady place. Calculations of samples were done following Lackey's drop count methods (Lackey, 1938).

Planktonic volumes were directly converted to unit $\mathrm{L}^{-1}$. Periphyton samples were scrapped from a known surface area of submerged bamboo, centrifuged and reduced to $10 \mathrm{ml}$ with $4 \%$ formalin. The abundance thus obtained was expressed in unit $\mathrm{L}^{-1}$. It was converted to unit $\mathrm{L}^{-1} \mathrm{~cm}^{-2}$ by the following formula-

Unit $\mathrm{L}^{-1} \mathrm{~cm}^{-2}=$ unit $\mathrm{L}^{-1}$ from substrate/ area scrapped for periphyton $(\mathrm{cm})$

Mean value was expressed as parentage abundance on total abundances for a sampling period.

\section{Diversity measures}

The Shannon Wiener Diversity Index, $\mathrm{H}$ ' was calculated on the basis of the number of taxa (here genus) and individual abundance of organisms present in the sample (Shannon and Wiener, 1949).

$$
\mathrm{H}^{\prime}=-\sum \mathrm{Pi} \ln \mathrm{Pi}
$$

Where, $\mathrm{H}^{\prime}$ is the Shannon Wiener Diversity Index $\mathrm{Pi}$ is the fraction of abundance of ith taxon to total number of individuals of all taxon in hand

Evenness index, $(\mathrm{J})$ of diversity based on $\mathrm{H}^{\prime}$ was also determined.

It was calculated on the basis of $\mathrm{H}^{\prime}$.

$\mathrm{J}=\mathrm{H}^{\prime} / \mathrm{H}_{\max }$ (Pielou, 1966)

Where, $\mathrm{J}$ is the evenness measure

$\mathrm{H}^{\prime}$ is the Shannon Wiener Diversity Index

$\mathrm{H}^{\prime}{ }_{\max }$ is the maximum value of $\mathrm{H}^{\prime}, \mathrm{H}^{\prime}{ }_{\max }=\mathrm{lnS}$, (Fager, 1972), S denotes richness of plankton.
Percentage abundance has been expressed for both plankton and periphyton.

\section{RESULTS}

Richness of plankton and periphyton showed almost equal number of genera of algae in the pond (Table 1). For plankton and periphyton, generic richness of Cyanophyceae, Bacillariophyceae and Euglenophyceae were recorded as 6, 6 and 3 respectively. Chlorophyceae with generic richness of 10 and 9 in plankton and periphyton respectively, were maximum in both cases. Euglenophyceae like Phacus, made highest species representation in periphyton. From Table 1, it is evident that all planktonic Cyanophyceae members exhibited periphytic mode of life. For Chlorophyceae, except Scenedesmus bijugatus, Ankistrodesmus sp. and Cosmarium sp., all other planktonic members exhibited periphytic life. In Bacillariophyceae, Sellaphora pupula exhibited only periphytic life, while other members were recorded as planktonic too. In Euglenophyceae, except two species (Phacus acuminatus and Phacus lemmermanni), all other Phacus sp. exhibited periphytic life.

Percentage abundances showed that Euglenophyceae were more abundant at early stage in both plankton and periphyton than late stage of the study (Figure 1). In July 2012, planktonic Euglenophyceae were higher (30\%) than periphyton (21.4\%). The latter further reduced from $21.4 \%$ to $17.9 \%$ during this period. In contrast, Chlorophyceae showed opposite trends of abundances in both environments. In early period of sampling (i.e. July), planktonic Chlorophyceae constituted $21.4 \%$ of total algal abundance which reduced to $17.9 \%$ in December, whereas for periphytic Chlorophyceae, the same contributed $13.6 \%$ to total algal periphytic composition in July and increased to $18.2 \%$ in December. Bacillariophyceae showed mixed results in case of phytoplankton. During November, it showed maximum abundance $(22.7 \%)$. For periphyton, the percentage abundance increased steeply from $3.8 \%$ in July to $19.2 \%$ in December. During October, it exhibited maximum abundance (26.9\%). Planktonic Cyanophyceae also showed steep increase from $9.5 \%$ to $19 \%$ whereas in case of periphyton, there was a marginal increase $(15.4 \%$ to $19.2 \%)$.

Table 1. Richness and generic diversity of plankton and periphyton from freshwater pond stocked with $L$. rohita. a available as plankton; available as periphyton.

\begin{tabular}{|c|c|c|c|}
\hline Cyanophyceae & Chlorophyceae & Bacillariophyceae & Euglenophyceae \\
\hline Aphanocapsasp ${ }^{a b}$ & Ankistrodesmussp. ${ }^{a}$ & Navicula sp. ${ }^{a b}$ & Trachelomonus sp. ${ }^{a b}$ \\
\hline Aphanocapsa roeseana ${ }^{b}$ & Scenedesmussp. . $^{a b}$ & Sellaphora pupula & Phacus sp. ${ }^{a}$ \\
\hline Chroococcus sp. ${ }^{a b}$ & Scenedesmus bijugatus ${ }^{a}$ & Synedra sp. ${ }^{a b}$ & Phacus unguis ${ }^{a b}$ \\
\hline Oscillatoria sp. ${ }^{a b}$ & Scenedesmus acutus ${ }^{a b}$ & Pinnularia sp.ab & Phacus acuminatus ${ }^{a}$ \\
\hline Phormidium willeib & Kirchenerilla sp.ab & Surrirela sp. ${ }^{a b}$ & Phacus chloroplastes \\
\hline Gloeocapsa sp. ${ }^{a b}$ & Closterium sp. ${ }^{a b}$ & Nitzschia sp. ${ }^{a b}$ & Phacus tortuosus ${ }^{b}$ \\
\hline \multirow[t]{7}{*}{ Hapalosiphon sp. ${ }^{a b}$} & Oedogonium sp. ${ }^{a b}$ & Gyrosigma sp. $^{a b}$ & Cryptoglena skujae ${ }^{b}$ \\
\hline & Tetmemonas sp. ${ }^{a b}$ & & Phacuswettsteinitib \\
\hline & Ulothrix sp. ${ }^{a b}$ & & Euglena sp. ${ }^{a b}$ \\
\hline & Characium sp & & Euglena sanguinea ${ }^{a b}$ \\
\hline & Cosmarium sp. ${ }^{a}$ & & \\
\hline & Cosmarium pseudopyramidatumb & & \\
\hline & Gloeocystis sp. ${ }^{b}$ & & \\
\hline
\end{tabular}




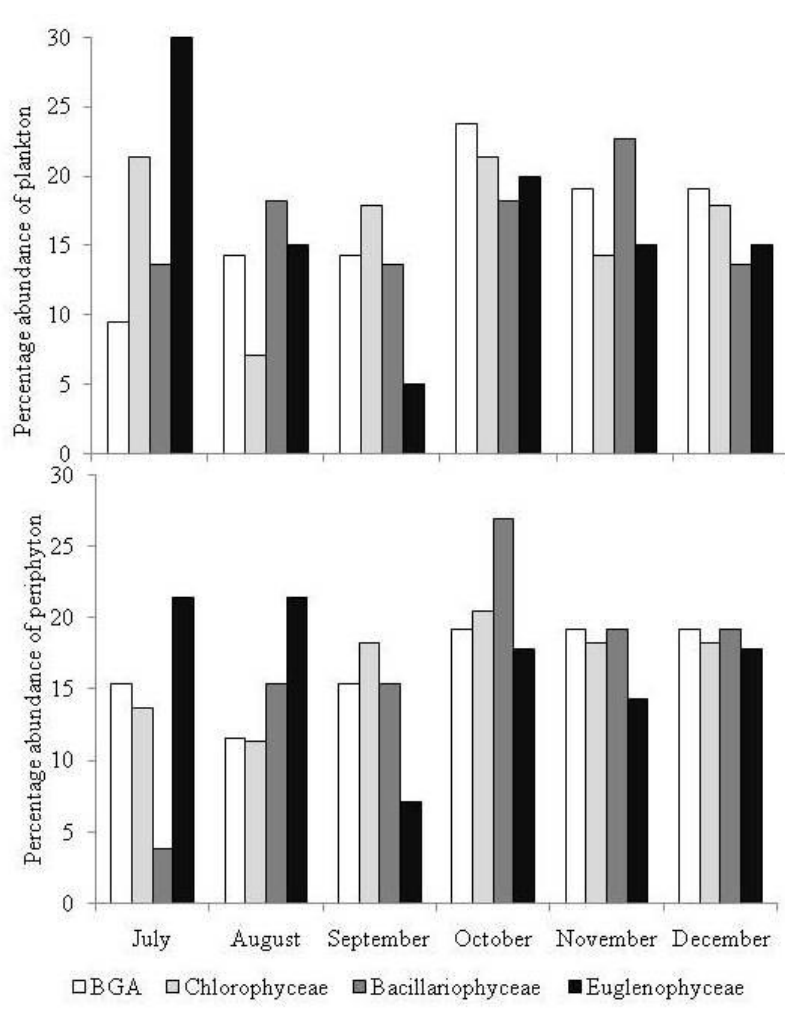

Figure 1. Percentage abundances of plankton (top) and periphyton (bottom) from pond stocked with L. rohita. BGA, Blue Green Algae (Cyanophyceae)

All sampling periods showed high Shannon Wiener diversity in respect of Shannon's maximum diversity $\left(\mathrm{H}_{\max }\right)$ counted on total generic richness (Table 2). These diversity indices were ranged from 1.07 to 1.20 for plankton. In case of periphyton, this range was 1.15 to 1.36 . Evenness indices (J) also showed highly homogenous distribution (around 9.0) for both plankton and periphyton throughout all sampling periods.

Table 2. Diversity indices of plankton and periphyton from pond stocked with $L$. rohita recorded during 2012

\begin{tabular}{lcccccc}
\hline & \multicolumn{3}{c}{ Plankton } & \multicolumn{3}{c}{ Periphyton } \\
\cline { 2 - 7 } & $\mathbf{H}$ & $\mathbf{H}_{\max }$ & $\mathbf{J}$ & $\mathbf{H}$ & $\mathbf{H}_{\max }$ & $\mathbf{J}$ \\
\hline July & 1.18 & 1.30 & 0.91 & 1.26 & 1.38 & 0.91 \\
August & 1.07 & 1.15 & 0.94 & 1.15 & 1.32 & 0.87 \\
September & 1.15 & 1.20 & 0.95 & 1.28 & 1.34 & 0.95 \\
October & 1.20 & 1.32 & 0.91 & 1.35 & 1.45 & 0.94 \\
November & 1.13 & 1.26 & 0.90 & 1.25 & 1.38 & 0.91 \\
December & 1.19 & 1.23 & 0.97 & 1.32 & 1.42 & 0.93 \\
\hline
\end{tabular}

\section{DISCUSSION}

An almost indifferent generic richness between phytoplankton and periphyton indicates random choice of planktonic algal members to exhibit periphytic life-style throughout the study period. Saikia et al. (2013a) stated an attachment procedure of plankton to pre-existing aquatic biofilm for the formation of periphytic layer. Generally, planktonic algal members adopt a preferential choice for periphytic life in aquatic ecosystem. Most algae always prefer for periphytic life, some of which rapidly colonize on available substrate. Except Euglenophyceae, all other algal groups maintained both planktonic as well as periphytic life style.

Richness of periphyton in the pond studied was found to be very less compared to similar other water bodies. Earlier Saikia and Das (2009b) studied periphyton and plankton from rice fields stocked with Cyprinus carpio (L.) and recorded higher richness of periphyton in it than that of freshwater pond environment. Thus richness of these organisms might be influenced by biotic and abiotic components specific to the ecosystem. Wahab et al. (1999) reported 25 genera of Chlorophyceae, 12 genera of Bacillariophyceae, 10 genera of Cyanophyceae from bamboo substrate stocked with Labeo calbasu $(H$.) in freshwater pond. The role of grazer (i.e Labeo rohita in the present study) in determining algal richness could not be ignored. Depending on the ecosystem, grazer may affect algal growth through grazing activities and thereby influencing algal diversity or algal accumulation rates on substrate (Vanni et al., 2006, Gruner et al., 2008, Murdock et al., 2010). However, percentage abundances showed that Bacillariophyceae and Cyanophyceae mostly prefer periphytic life over planktonic life. Preference of Bacillariophyceae to exhibit periphytic life on organic substrates over planktonic life has been reported earlier (Bere, 2010). Cyanophyceae too, exhibited similar mode of preference. In presence of rohu, such preferential exhibition by Bacillariophyceae and Cyanophyceae was not reported earlier. Both these two genera are considered as best algal candidates to colonize on bacterial biofilm surfaces (Williams et al., 2000). They develop rapidly on substrate in absence of herbivores in aquatic phase (Williams et al., 2000). In presence of herbivores, few algal members may maintain a persistent growth on substrate surface (Williams et al., 2000). Probably, rohu with herbivorous feeding habit either avoid these genera or selectively feed on other periphytic forms. Saikia et al. (2013b) proposed that the fish rohu could explore a sub-periphytic zone found in proximity to periphytic surfaces. In such cases it is truly a filter feeder, not a grazer. Shifting of filter feeding activity by rohu to such specific zone in substrate installed environment could be the reason that led to indifferent in richness of planktonic and periphytic algal communities. Supporting a probability of such interaction, the Shannon Wiener index also reflected high ranges of diversity for both plankton and periphyton. All diversity measures were very close to expected maximum Shannon Wiener diversity. Evenness $(\mathrm{J})$ values clearly support such closeness. Both Shannon-Wiener diversity and evenness results explained the effect of grazer presence on planktonic and periphytic communities. It is well established that presence of grazer increases the heterogeneity and primary productivity of periphytic algal groups (Saikia et al., 2011). Grazers, like rohu with wide mouth might follow filter feeding behaviour reducing competition among plankton in water column to colonize on substrate and browse on algal members nearing to substrate and thereby clears new patches for microalgae 
to grow rapidly on the submerged substrate. Such regulation, especially on periphyton, often tends to increase algal heterogeneity in the system (Saikia et al., 2011).

Thus, presence of rohu in a periphyton based pond ecosystem does not negatively affect algal communities, rather, enhances their heterogeneity and richness in water column as well as on substrate. Such enhancement could be either through selective feeding on macro- and filamentous

\section{REFERENCES}

APHA, 1998. Standard Methods for the Examination of Water and Wastewater, 20th Edition, Americal Public Health Association.

Bere, T., 2010.Benthic diatom community structure and habitat preferences along an urban pollution gradient in the Monjolinho River, São Carlos, SP, Brazil. Acta Limnologica Brasiliensia, 22(1): 80-92. doi: $10.4322 /$ actalb.02201011

Dawes, C. J., 1998. Marine Botany. 2nd edition. John Wiley and Sons Inc. New York, NY

Edmondson, W.T., 1992. Freshwater biology. International books and periodicals supply services, New Delhi, India.

Fager, E.W., 1972. Diversity: a sampling study. American Naturalist, 106:293310. doi: $10.1086 / 282772$

Feminella, J.W., Hawkins, C. P., 1995. Interactions between stream herbivores and periphyton: a quantitative analysis of past experiments. Journal of the North American Benthological Society, 14:465-509. doi: $10.2307 / 1467536$

Gruner, D. S., Smith, J. E., Seabloom, E.W., Sandin, S. A., Ngai, J. T., Hillebrand, H., Harpole, W. S., Elser, J. J., Cleland, E. E., Bracken, M. E. S., Borer, E. T., Bolker, B. M., 2008. A cross-system synthesis of consumer and nutrient resource control on producer biomass. Ecology Letters, 11:740-755. doi: 10.1111/j.1461-0248.2008.01192.x

Lackey, J.B., 1938.The manipulation and counting of river plankton and changes in some organisms due to formalin preservation. Public Health Reports, 53: 2080p. doi: 10.2307/4582717

Lewis, W.M. Jr., 1974. Primary production in the plankton community of a tropical lake. Ecological Monographs, 44: 377-409. doi: $10.2307 / 1942447$

Murdock, J. N., Gido, K. B., Dodds, W. K., Bertrand, K. N., Whiles. M. R. 2010. Consumer return chronology alters recovery trajectory of stream ecosystem structure and function following drought. Ecology, 91:10481062. doi: $10.1890 / 08-2168.1$

Pielou, E.C., 1966. Shannon's formula as a measure of species diversity: its use and misuse. American Naturalist, 100: 463-465. doi: $10.1086 / 282439$

Pentecost, A., 1984. Introduction to Freshwater Algae. 1st edn. The Richmond Publishing Company Limited, Orchard Road, Richmond, Surrey, England. algae from water column or random selection from a plankton -periphyton interface zone, as proposed by Saikia et al. (2013b).

\section{ACKNOWLEDGEMENT}

Authors acknowledge University grants Commission, New Delhi, India for financial assistance through Major Research Project to conduct this work.

Rahman, M.M., Verdegen, M.C.J., Nagelkerke, M.A., Verreth, J.A.J., 2008. Swimming, grazing and social behaviour of rohu Labeo rohita (Hamilton) and common carp Cyprinus carpio (L.) in tanks under fed and non-fed conditions. Applied Animal Behaviour Science, 113(1-3): 255-264. doi: 10.1016/j.applanim.2007.09.008

Saikia, S.K., Das, D.N., 2009a. Potentiality of Periphyton-based Aquaculture Technology in Rice-fish Environment. Journal of Scientific Research, 1 (3): 624-634

Saikia, S.K., Das, D.N., 2009b. Diversity and similarity of algal communities from upland rice-fish environment: A case study. International Journal of Ecology and Development, 14 (9): 74-78.

Saikia, S.K., Roy, S., Mukherjee, J., 2011. The Upside of Grazer-Periphyton Interactions: A Review. In: Zooplankton and Phytoplankton: Types, Characteristics and Ecology (Ed. GiriKattel) Nova Science Pubishers Inc, UK p.89-106

Saikia, S.K., Nandi, S., Majumder, S., 2013a. A review on the role of nutrients in development and organization of periphyton. Journal of Research in Biology, 3(1): 780-788.

Saikia, S.K., Majumder, S., Nandi, S., Saha, S.K., 2013b. Feeding ecology of the freshwater fish Rohu, Labeo rohita (Hamilton 1822): A case of intelligent feeding in the periphyton-based environment. Zoology and Ecology, 23(4): 266-274. doi: 10.1080/21658005.2013.859849

Shannon, C.E., Wiener, W., 1949. The mathematical theory of communication. University of Illinois Press, Urbana, IL: University of Illinois Press.

Vanni, M. J., Bowling, A. M., Dickman, E. M., Hale, R. S., Higgins, K. A., Horgan, M. J., Knoll, L. B., Renwick, W. H., Stein. R. A., 2006. Nutrient cycling by fish supports relatively more primary production as lake productivity increases. Ecology, 87:1696-1709. doi: 10.1890/0012-9658(2006)87[1696:NCBFSR]2.0.CO;2

Wahab, M.A., Azim, M.E., Ali, M.H., Beveridge, M.C.M., Khan, S. 1999. The potential of periphyton based culture of the native major carp Calbasu, Labeo calbasu (Hamilton). Aquaculture Research, 30 (6): 409-419. doi: 10.1046/j.1365-2109.1999.00337.x

Williams, G. A., Davies, M. S., Nagarkar, S.,2000. Primary succession on a seasonal tropical rocky shore: the relative roles of spatial heterogeneity and herbivory. Marine Ecological Progress Series, 203: 81-94. 